\title{
Prevalence of Coccidian Species in the Water Buffalo (Bubalus Bubalis) in the Province of Afyon, Turkey
}

\author{
S. NALBANTOGLU, B. SARI ${ }^{1}$, H. CICEK ${ }^{2}$, Z. KARAER \\ Department of Parasitology, Faculty of Veterinary Medicine \\ University of Ankara, Ankara, Turkey \\ ${ }^{1}$ Department of Parasitology, Faculty of Veterinary Medicine \\ University of Kafkas, Kars, Turkey \\ ${ }^{2}$ Department of Parasitology, Faculty of Veterinary Medicine \\ University of Afyon Kocatepe, Afyon, Turkey
}

Received January 29, 2007

Accepted February 14, 2008

\begin{abstract}
Nalbantoglu S., B. Sari, H. Cicek, Z. Karaer: Prevalence of Coccidian Species in the Water Buffalo (Bubalus Bubalis) in the Province of Afyon, Turkey. Acta Vet. Brno 2008, 77: 111-116.

The objective of this study was to identify the coccidian species present in water buffaloes in the vicinity of Afyon. Faecal samples were collected directly from the rectum of a total of 104 water buffaloes, and examined in the laboratory using Sheather's saturated sugar solution. Faecal samples found to contain Eimeria species were mixed with a solution of $2.5 \%$ potassium dichromate, left at room temperature in petri dishes until the oocysts sporulated, and then examined in order to identify the species.

Eleven different Eimeria species and one Isospora species were identified in $78(75 \%)$ out of the 104 water buffaloes as follows: E. zuernii (55.1\%), E. auburnensis (44.9\%), E. bovis (44.9\%), E. ellipsoidalis $(28.2 \%)$, E. ankarensis $(16.7 \%)$, E. subspherica $(16.7 \%)$, E. alabamensis $(11.5 \%)$, E. cylindrica $(10.3 \%)$, E. bareillyi $(5.1 \%)$, E. canadensis $(5.1 \%)$, E. brasiliensis $(3.8 \%)$, and Isospora spp. $(46.2 \%)$. With this study, species causing coccidiosis in water buffaloes in the province of Afyon were identified for the first time, and Isospora spp. in the water buffalo is reported for the first time.
\end{abstract}

Water buffalo, coccidiosis, Eimeria, Isospora, Afyon, Turkey

Coccidiosis is an intestinal disease that affects several different animal species including cattle, sheep, goats, cats, water buffalo, dogs, rabbits, and poultry. Since the disease may result in death especially in young animals, it is the cause of a considerable economic loss in farm animals world-wide (Levine 1985; Mimioglu et al. 1969; Pellèrdy 1974; Soulsby 1982). Coccidian species generally have host specificity, and in this respect the species of E. ankarensis, E. azerbaidjanica, E. bareillyi, E. gokaki, E. ovoidalis and E. thianethi have been reported in water buffaloes. Moreover, species found in cattle, such as Eimeria alabamensis, E. auburnensis, E. bovis, E. brasiliensis, E. bukidnonensis, E. canadensis, E. cylindrica, E. ellipsoidalis, E. subspherica, E. wyomingensis, and E. zuernii have also been reported in the water buffalo (Levine 1985; Pellèrdy 1974; Sayin 1968; Soulsby 1982).

Apart from E. azerbaidjanica and E. thianethi which are specific to the water buffalo (Patnaik 1964; Patnaik 1965; Patnaik and Pande 1965; Pellèrdy 1974; Yakimoff 1933), various cattle Eimeria species have been generally reported to prevail in the world (Gundran and More 1999; Patnaik 1964; Patnaik 1965; Patnaik and Pande 1965; Tubangui 1931; Yakimoff 1933). In addition, the endogenous development of some Eimeria species in the small intestine (duodenum, jejunum and ileum) of the water buffalo has been defined histologically (Patnaik 1965; Patnaik and Pande 1965).

The population of water buffaloes was 104,965 in Turkey in 2005. The Afyon province

Address for correspondence:

Dr. Baris Sari, Assistant Professor

University of Kafkas

Faculty of Veterinary Medicine

Department of Parasitology

Phone: +90 474242 6800-ext. 1143

Fax: +90 4742426853

36100 Kars, Turkey

E-mail: bsari67@hotmail.com; or bsari6767@yahoo.com

http://www.vfu.cz/acta-vet/actavet.htm 
has $3.4 \%(3,953)$ of the total population. Although this number seems to be low, the milk of water buffaloes is very important in the Afyon area. The Afyon province is the homeland of a special dessert made of water buffalo milk, known as "Afyon kaymagi" (Anonymous 2007; Anonymous 2007a).

There are very limited studies on the parasites of water buffaloes in Turkey. The studied parasites are mostly helminths. The prevalence of Paramphistomum spp. was $66.6 \%$ (Guralp 1981) and that of Calicophoron daubneyi was 9.75\% (Tinar et al. 1992). Some helminth parasites were reported for the first time, such as Monezia expensa, Avitellina centripunctata, Gonglyonema pulchrum, Artionema labiato-papillosa, and Paracooperia nodulosa in water buffaloes (Merdivenci and Buyurman 1965; Tuzdil 1939; Guralp and Dogru 1968; Cetindag 1993). In the Samsun province, 100 water buffaloes were slaughtered and the parasites of the gastrointestinal system were investigated. Thirteen species ( 1 trematode and 12 nematoda) were found. Coccidia oocysts were found in $21 \%$ of the animals and also Sarcocystis macrocysts and microcysts were encountered in $13 \%$ of the oesophagus of the animals (Cetindag and Doganay 1996). Dundar and Ozer (1996) reported that Sarcocystis cysts were encountered in the oesophagus of water buffaloes as $39.2 \%$ macroscopically and $81.6 \%$ microscopically. No studies were done on the coccidian parasites in water buffaloes in the Afyon province previously. The prevalence of coccidian species in cattle is as follows: Eimeria bovis $(34.55 \%)$, E. auburnensis $(23.03 \%)$, E. canadensis $(14.55 \%)$, E. brasiliensis $(10.91 \%)$, E. zuernii $(6.67 \%)$, E. bukidnonensis $(3.03 \%)$, E. cylindrica $(2.42 \%)$, E. ellipsoidalis (1.21\%), E. illinoisensis $(1.21 \%)$, E. alabamensis (1.21\%) and Isospora spp. (1.21\%) (Cicek et al. 2007).

The first study on coccidiosis in water buffaloes in Turkey, conducted by Sayin (1968), found only one water buffalo-specific Eimeria spp., E. ankarensis, alongside the cattle species E. ellipsoidalis, E. zuernii, E. bovis, E. auburnensis, E. canadensis, E. subspherica, E. alabamensis, E. cylindrica, E. brasiliensis and E. wyomingensis in water buffalo. Eimeria ankarensis was recorded as a new species in water buffaloes in this study, which also investigated the potential of E. ankarensis, E. zuernii, E. auburnensis, E. ellipsoidalis and $E$. bovis oocysts from the water buffalo to infect cattle calves, and found that with the exception of $E$. ankarensis, the other species could infect cattle. Therefore, E. ankarensis was classified as host-specific for the water buffalo. In another study on water buffaloes, Sayin (1973) reported the presence of E. bareillyi for the first time in Turkey.

No studies were done on the coccidian parasites in water buffaloes in the Afyon province previously. This study was conducted with the aim of identifying the coccidian species present in water buffaloes in the Afyon province and determining their prevalence.

\section{Materials and Methods}

This study was performed between 2002 and 2004 in the villages of Oren and Akcin in the Afyon province, where the raising of water buffaloes is common. The pastures where water buffaloes graze are also shared by cattle and sheep. The city has a continental climate: hot and dry summer, mild and rainy spring, cold and snowy winter.

Faecal samples were taken from the animals simultaneously. Faecal samples were collected directly from the rectum of a total of 104 water buffaloes, 40 of which were younger than 1 year of age, and the remaining 64 were older than 1 year; 54 of them were from Oren and 50 from Akcin villages, respectively. The samples were collected into plastic bags that were labelled and taken to the laboratory.

In the laboratory, after 3 washes, the sediment from each sample was mixed with Sheather's saturated sugar solution, centrifuged and examined under a microscope for the presence of protozoan oocysts. Samples containing coccidian oocysts were mixed with $2.5 \%$ potassium dichromate in petri dishes and left at room temperature for the sporulation of oocysts to take place. Species were then identified according to the size and morphological characteristics of the oocysts (the shape and colour of the oocysts; the thickness of the oocyst walls; the presence of micropyl, cap, polar granules, and oocyst or sporocyst deposits, the size and shape of the sporocysts, the shape of Stieda bodies and sporozoites, etc.). The identification of each species was made with reference to the measurements of 25 to 50 oocysts, from at least 5 hosts (or from the total number of hosts if less than 5), under a research microscope (Olympus) with a camera attachment. 


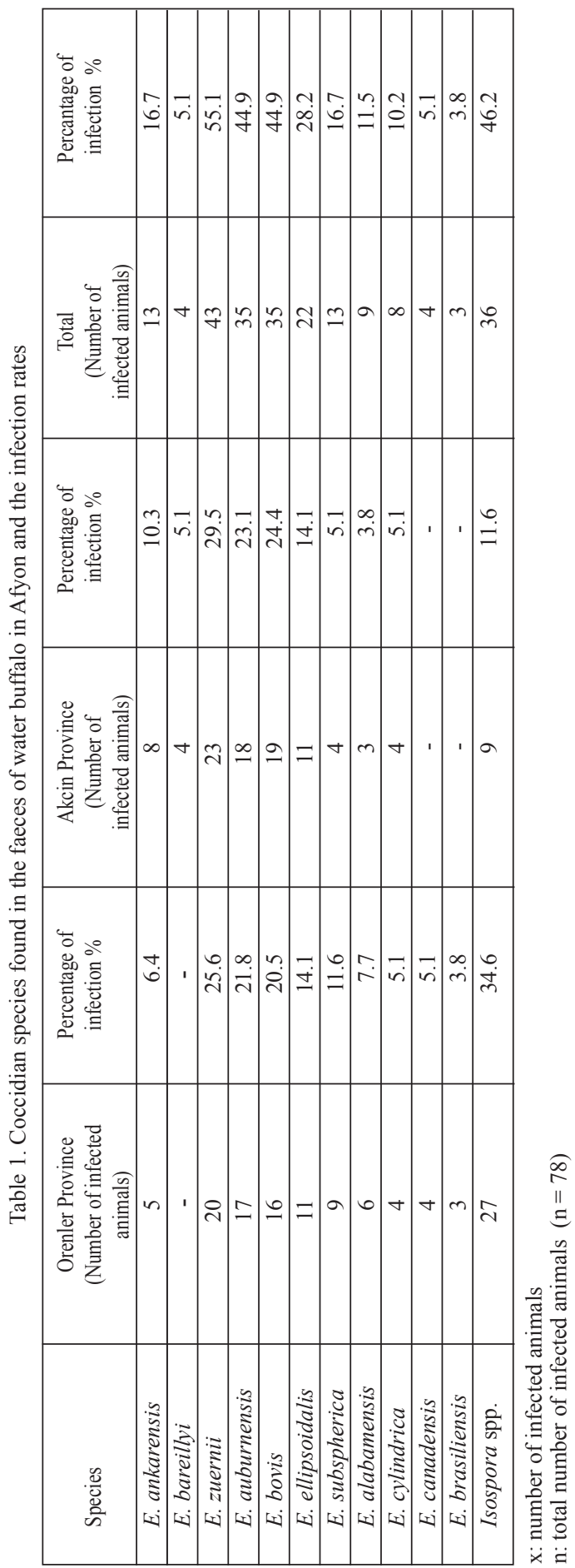

Statistical differences in the prevalence of coccidiosis between the age groups were determined using the Chi-square test.

\section{Results}

Seventy eight (75\%) out of 104 water buffaloes were found to be infected with coccidian species. Faecal samples from 20 animals $(25.6 \%)$ contained only 1 species; from $19(24.4 \%), 2$ species; from 14 (17.9\%), 3 species; from $13(16.7 \%), 4$ species; from 3 $(3.8 \%), 5$; from $6(7.7 \%), 6$; from 2 (2.6\%), 7 and from 1 animal (1.3\%), 8 species. Infections with single species were found as follows: 13 animals were infected (65\%) with Isospora spp., 2 animals (10\%) with E. auburnensis, 5 $(25 \%)$ animals with $E$. ankarensis, $E$. bovis, E. ellipsoidalis, E. cylindrica and $E$. zuernii, respectively.

Table 1 shows the coccidian species found and the rate of infection caused by each species. As seen in this table, a total of 11 Eimeria species and one Isospora spp. (Plate XI, Fig. 3) were found in water buffaloes. Eimeria bareillyi in the Orenler district and $E$. canadensis and E. brasiliensis in the Akcin district were not encountered. Two of the Eimeria species (E. ankarensis and E. bareillyi) (Plate XI, Fig. 1 and 2) were specific to the water buffalo, and the rest were cattleoriginated species (E. zuernii, $E$. auburnensis, E. bovis, E. ellipsoidalis, E. subspherica, E. alabamensis, E. cylindrica, E. canadensis, and E. brasiliensis). The rate of infection caused by E. ankarensis, E. zuernii, E. auburnensis, and E. bovis was higher than that of the remaining species (Table 1).

Furthermore, 37 (92.5\%) out of 40 water buffaloes less than 1-yearold and $41(64.1 \%)$ out of 64 older than 1 year were found to be infected with various coccidian species. The difference between the rates of infection among the age groups was found to be statistically significant 


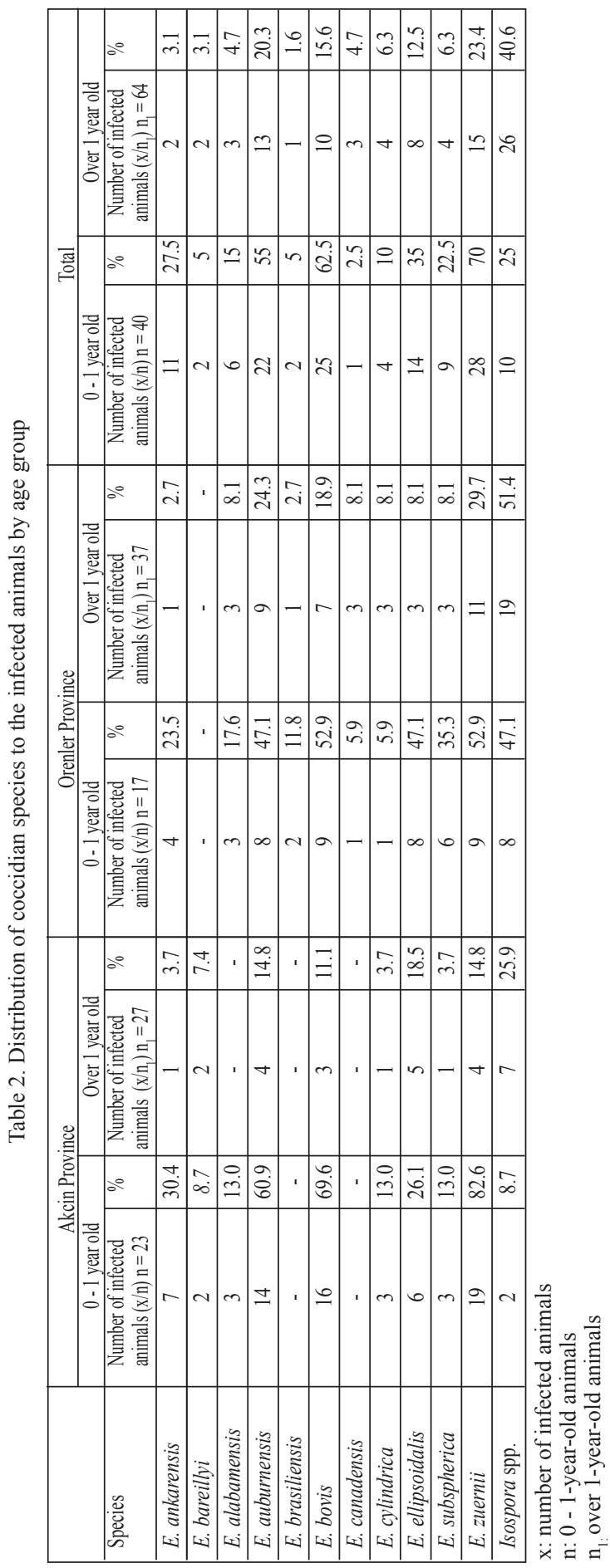

$(P<0.001)$. The distribution of these species to the infected animals in each age group is given in Table 2. It is understood from this table (Table 2) that all coccidia species except E. canadensis are more prevalent in 0 to 1-yearold animals. E. brasiliensis and E. canadensis were not seen in 0-to-1-year-old water buffaloes in the Akcin district. Eimeria alabamensis was not seen in water buffaloes older than 1 year in the Akcin district. Eimeria bareillyi was not found in all of the water buffaloes in the Orenler district.

A high proportion $(46.2 \%)$ of the water buffaloes was found to be infected with only one Isospora spp. in this study. The oocysts of this species measured $22.35 \times$ $24.09(18.3-31.11 \times 18.3-31.84)$ micrometres and were rounded, with double straight walls and no oocyst deposits. The sporocysts of the sporulated oocysts measured on average of $9.54 \times 14.02(12.81$ - $18.3 \times 7.32-10.98)$ micrometres and were prominent, club-shaped, with button-shaped Stieda bodies, and deposits of sporocyst remains (Fig. 3).

\section{Discussion}

Six out of 17 of the recorded Eimeria species that infect the water buffalo ( $E$. ankarensis, E. azerbaidjanica, E. bareillyi, E. gokaki, E. ovoidalis, and E. thianethi) throughout the world are known to be specific to the water buffalo, while the remaining 11 species ( $E$. alabamensis, E. auburnensis, E. bovis, E. brasiliensis, E. bukidnonensis, E. canadensis, E. cylindrica, E. ellipsoidalis, E. subspherica, E. wyomingensis, and E. zuernii) are cattle-originated (Arslan 2001; Gundran and More 1999; 
Patnaik 1964; Patnaik 1965; Patnaik and Pande 1965; Penzhorn 2000; Ribeiro et al. 2000; Sayin 1968; Tubangui 1931; Yakimoff 1933). In this study, a total of 11 Eimeria species were found in water buffaloes from the Afyon province, of which 2 were specific to the water buffalo (E. ankarensis and E. bareillyi), and the remaining 9 were of cattle origin (E. alabamensis, E. auburnensis, E. bovis, E. brasiliensis, E. canadensis, E. cylindrica, E. ellipsoidalis, E. subspherica, and E. zuernii). Furthermore, one Isospora sp., the origin of which is open to discussion, was also identified, for the first time in the world, in a large number of water buffaloes $(46.2 \%)$.

In one of the two other studies performed on water buffaloes in Turkey (Sayin 1968), (95.4\%) 124 out of 130 water buffaloes in the vicinities of Ankara, Adapazari, Bolu, Corum, Kayseri and Samsun, and in the second study (Sayin 1973),(2\%) 1 out of 50 water buffaloes from Adapazari, were found to be infected with Eimeria species. The identification of the species revealed that 2 were specific to the water buffalo $(2 \% E$. bareillyi and $9.9 \% E$. ankarensis) and 10 were of cattle origin (53\% E. ellipsoidalis, $48.8 \%$ E. zuernii, $43.8 \%$ E. auburnensis, 34.4\% E. bovis, 20\% E. canadensis, $15.3 \%$, E. subspherica, $10.3 \%$ E. alabamensis, $4.6 \%$ E. cylindrica, $1.6 \%$ E. brasiliensis, and $0.7 \%$ E. wyomingensis). That research also identified and described $E$. ankarensis for the first time in the world, and reported the occurrence of $E$. bareillyi in the water buffalo for the first time in Turkey. In our study, 78 (75\%) out of 104 water buffaloes from the province of Afyon were found to be infected with 11 different Eimeria species, 2 of which were recorded as specific to the water buffalo and the remainder of which originated from cattle. The presence of all these species, with the addition of E. wyomingensis, was reported in water buffaloes in Turkey in the two previous studies. In our study, Isospora spp. was reported for the first time in the water buffalo.

We found 8 Eimeria and Isospora species which were also found in a study (Cicek et al. 2007) carried out on cattle in the Afyon province, where we also performed our study. This shows that the species we found might be cattle-originated. In the same study it was noted that younger animals $(27.23 \%)$ showed higher prevalence of coccidial infection than older animals (15.65\%). In our study the infection rate was $92.5 \%$ in animals younger than 1 year and $64.1 \%$ in animals older than 1 year. Infection rates were compatible with the study of Cicek et al. (2007) regarding the effect of age on infection rates.

In conclusion, this study showed that $75 \%$ of water buffaloes in the Afyon province were infected with 11 different Eimeria species, 2 of which were host-specific to water buffaloes and 9 of which were of a cattle origin. A high number of the water buffaloes were found to be infected with a novel Isospora species which warrants further detailed studies.

\section{Výskyt jednotlivých druhů kokcidií u buvola indického (Bubalus Bubalis) v Turecku, provincie Afyon}

Cílem této studie bylo identifikovat jednotlivé druhy kokcidií vyskytující se u buvola indického v okolí Afyonu. Vzorky trusu byly odebrány př́mo z rekta 104 buvolů indických a zkoumány v laboratoři s využitím Sheatherova cukerného roztoku. Vzorky, u kterých byla zjištěna prítomnost Eimeria spp. byly smíchány s roztokem dichromanu draselného o koncentraci $2,5 \%$ a ponechány při pokojové teplotě na petriho miskách, dokud oocysty nevysporulovaly. Poté byly identifikovány jednotlivé druhy.

Bylo identifikováno jedenáct různých druhů Eimeria spp. a jeden Isospora spp. u 78 buvolů indických $(75 \%)$ ze 104 testovaných. Jednalo se o: E. zuernii $(55,1 \%)$, E. auburnensis (44,9\%), E. bovis (44,9\%), E. ellipsoidalis $(28,2 \%)$, E. ankarensis $(16,7 \%)$, E. subspherica $(16,7 \%)$, E. alabamensis $(11,5 \%)$, E. cylindrica $(10,3 \%)$, E. bareillyi $(5,1 \%)$, E. canadensis $(5,1 \%)$, E. brasiliensis $(3,8 \%)$, a Isospora spp. (46,2\%). V rámci této studie byly poprvé identifikovány druhy způsobující kokcidioźu buvolů indických v oblasti Afyon a byl u nich poprvé popsán výskyt Isospora spp. 


\section{References}

ANONYMOUS 2007: Basbakanlik Devlet Istatistik Enstitusu (The Institute of Statistics of the Prime Minister). Erişim http://www.tuik.gov.tr/PreIstatistikTablo.do?istab_id=681]. (accessed 15 August 2007)

ANONYMOUS 2007a: Afyonkarahisar Il Tarim Mudurlugu (Afyonkarahisar Provincial Agricultural Department). http://www.afyontarim.gov.tr/yapi/default.asp?sayfa=degerlendir.htm]. (accessed 15 August 2007)

ARSLAN MO 2001: Sigir ve Mandalarda Coccidiosis. (Coccidiosis in cattle and water buffaloes) (in Turkish) Dincer S. (Ed.). Coccidiosis. Turk Parazitol Derg Yay 17: 201-218

CETINDAG M 1993: Turkiye'de mandalarda yeni bir nematode turu Paracooperia nodulosa (Schwartz, 1928). (A new nematode species in Paracooperia nodulosa (Schwartz, 1928) in water buffaloes of Turkey) (in Turkish) Etlik Vet Mikrobiol Derg 7: 136-141

CETINDAG M, DOGANAY A 1996: Samsun yoresi mandalarında sindirim sistemi helmintleri. (Gastrointestinal helminths of buffaloes in the Samsun region) (in Turkish) Etlik Vet Mikrobiol Derg 8: 46-57

CICEK H, SEVIMLİ F, KOZAN E, KÖSE M, ESER M, DOGAN N 2007: Prevalence of coccidia in beef cattle in western Turkey. Parasitol Res 101: 1239-1243

DUNDAR B, OZER E 1996: Mandalarda bulunan Sarcocystis turleri ve gelismeleri. (Sarcocystis species and their developments in buffaloes) (in Turkish) Etlik Vet Mikrobiol Derg 8: 58-69

GUNDRAN RS, MORE SJ 1999: Health and growth of water-buffalo calves in Nueva Ecija, the Philippines. Prev Vet Med 40: 87-100

GURALP N: Helmintoloji. (Helminthology) (in Turkish) $2^{\text {nd }}$ Edition. Ankara Univ Vet Fak Yay 368: 266

GURALP N, DOGRU C 1968: Setaria infections of domestic animals in Turkey. Ankara Univ Vet Fak Derg 15: 29-40

LEVINE ND 1985: Veterinary Protozoology. Iowa State University Press, Ames, 414 p.

MERDIVENCI A, BUYURMAN U 1965: Turkiye'de koyun, keci, sigir ve mandalarda Anoplocephalata enfeksiyonlari uzerinde arastirmalar. (Investigations on Anoplocephalata infections in sheep, goat, cattle, and water buffaloes in Turkey) (in Turkish) Bornova Vet Ars Enst Derg 12: 79-100

MIMIOGLU M, GOKSU K, SAYIN F 1969: Veteriner ve Tibbi Protozooloji II. (Veterinary and Medical Protozoology II) (in Turkish) Ankara Univ Vet Fak Yay 248: 1129-1144

PATNAIK MM 1964: On the coccidian infections of buffalo calves. (A study of the oocysts). Agra Univ J Res 13: $239-256$

PATNAIK MM 1965: Observations on the effect of sulphadimidine on Eimeria bovis in naturally infected buffalo calves. Indian Vet J 42: 186-191

PATNAIK MM, PANDE BP 1965: Some observations on the endogenous stages of species of Eimeria and related lesions in naturally infected buffalo calves (Bubalus bubalis). Indian J Vet Sci 35: 33-46

PELLÉRDY LP 1974: Coccidia and Coccidiosis. Verlag Paul Parey, Berlin and Hamburg, 959 p.

PENZHORN BL 2000: Coccidian oocyst and nematode egg counts of free-ranging African buffalo (Syncerus caffer) in the Kruger National Park, South Africa. J S Afr Vet Assoc 71: 106-108

RIBEIRO MG, LANGONI H, JEREZ JA, LEITE DS, FERREIRA F, GENNARI SM 2000: Identification of enteropathogens from buffalo calves with and without diarrhoea in the Ribeira Valley, State of São Paulo, Brazil. Braz J Vet Res Anim Sci 37: 00-00. ISSN 1413-9596

SAYIN F 1968: The sporulated oocysts of Eimeria ankarensis n. sp. and of other species of Eimeria of buffalo in Turkey and transmission of four species of Eimeria from buffalo to cow calves. Ankara Univ Vet Fak Derg 15: $282-300$

SAYIN F 1973: The presence of Eimeria bareillyi (Gill, Chhabra and Lal, 1963) in buffalo in Turkey. Ankara Univ Vet Fak Derg 20: 38-42

SOULSBY ELJ (Ed.) 1982: Helminths, Artropods and Protozoa of Domesticated Animals. $7^{\text {th }}$ ed. Bailliere Tindall, London, $809 \mathrm{p}$.

TINAR R, COSKUN SZ, DOGAN H, DEMIR S, AKYOL CV 1992: Guney Marmara bolgesi ruminantlarında Amphistomum turlerinin bulunusu ve yayilisi. (The prevalence of Amphistomum spp. in ruminants of south Marmara region) (in Turkish) Turk J Vet Anim Sci 16: 187-197

TUBANGUI MA 1931: Eimeria bukidnonensis, a new coccidium from cattle, and other coccidial parasites of domesticated animals. Philipp J Sci 44: 253-273

TUZDIL AN 1939: Turkiye'de kasaplik hayvanlarda Gongylonema. (Gongylonema spp. in slaughtered animals of Turkey) (in Turkish)Yuksek Ziraat Enstitusu Calismalari. Sayi: 93, Ankara.

YAKIMOFF WL 1933 La coccdiose des animaux domestiques dans L'Azerbaidjan (Transcaucasia). Ann Soc Belp Med Trop 13: 93-130 
Plate XI

Nalbantoglu B. et al.: Prevalence of ... pp. 111-116
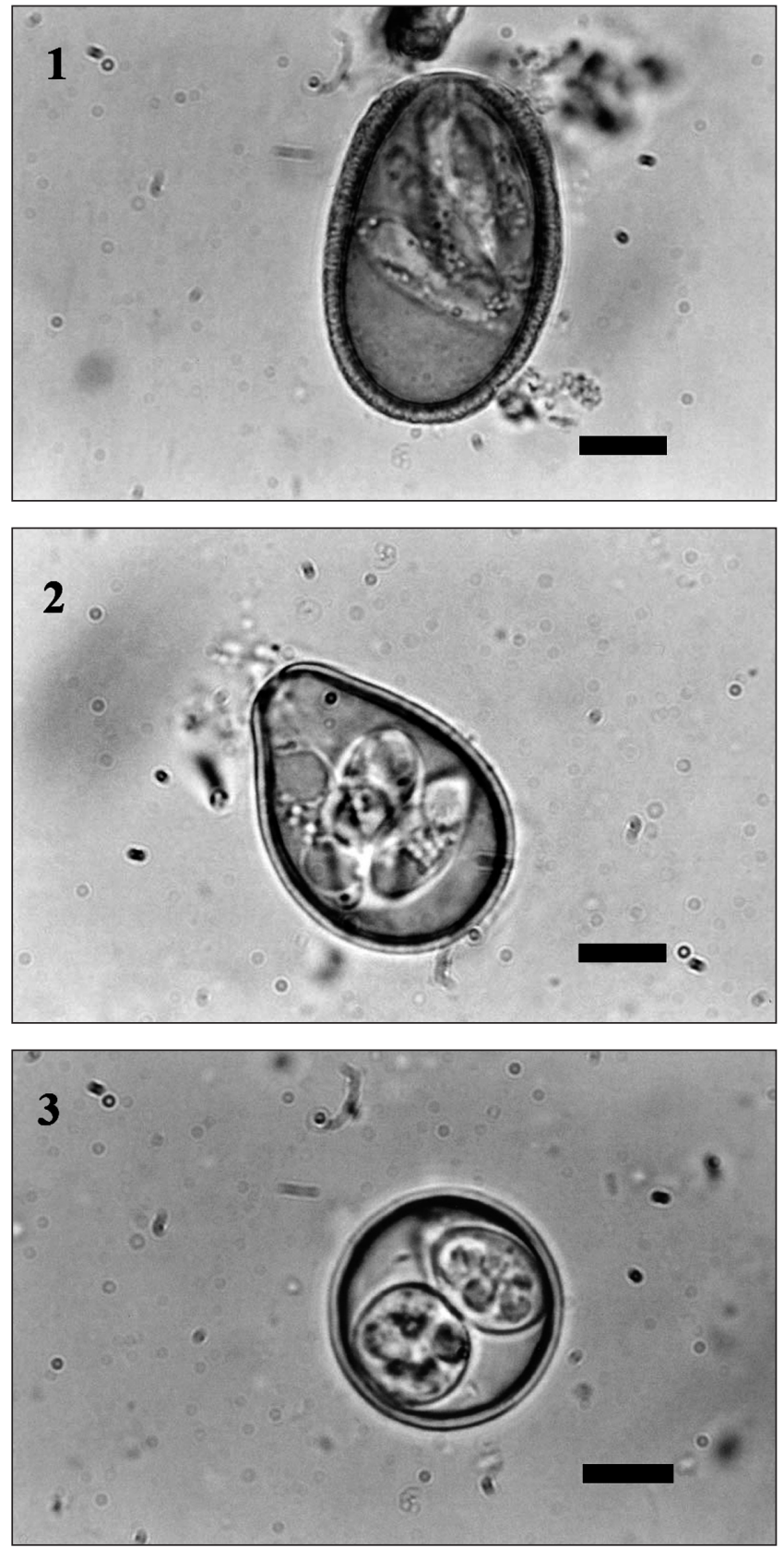

Fig. 1, 2 and 3. Sporulated oocysts of E. ankarensis, E. bareillyi and Isospora spp., respectively. $\operatorname{Bar}=10 \mu$ 